\title{
Changes in the employment market for information professionals?
}

\author{
MADELEINE LAQUEUR \\ Deloitte Touche Management Consultants (Netherlands)
}

\section{Summary}

Expanding upon the brief introduction given in LIRN 57, this article focuses upon some problems arising from the relationship between the education and training sector for information professionals and the employment market in the Netherlands.

As a result of the 1990 state-of-the-art study Functional analysis of the curricula in the information services sector new initiatives were taken by schools and training institutions, national organizations began innovative projects, and other studies were carried out such as the one summarized below.

In 1992 a survey New markets for the information professional? was carried out; a brief outline is given. This study explored the way educators and professional bodies in the libraries and information services sector respond to the developments in the employment sector, and specifically in the emerging new market.

The ensuing thorough assessment of curricula is described, as are reactions to the assessments from professional associations and practitioners.

\section{The relationship between the education and training sector for information professionals and the employment market in the Netherlands}

For quite some years now, a lively discussion has been going on in the Dutch information services sector on the way in which educators and professional bodies respond to the developments in the employment sector, in particular in the emerging market. It is assumed that there is a tension between the traditional employment market which is characterized mainly by the various types of libraries and information services and a broader market where information technology and commercial information set the trend. As changes in the information services sector are taking place at a very rapid pace, the characteristics of the tasks of information workers are changing or will change accordingly. As a natural consequence, education and training institutions will have to adapt swiftly to these changes. However, this in many instances is not the case. What could be the causes for this discrepancy?

On the one side, the educators aim at the general applicability of professional qualifications. During the education process, students will have to be able to choose and not start off with too specific an end. At the end of the course the student will be a professional debutante - with a good basic and theoretical knowledge - trained only to some extent in the practicalities. Training curricula intrinsically respond to long term aims: students of today will have to be prepared for work well into the next century. Finally, curricula are providing the requirements for the traditional market as well as the new emerging market.

On the other side of the fence, practice only demands practically skilled personnel. Information services both in the public and private sectors wish to satisfy short term needs and require professionals trained in relatively recent developments such as automation: there is now an enormous demand for personnel skilled in automation. Finally, every single information service or library will have individual and specific requirements for its professional staff.

A last probable explanation for the lack of mutual adaptation of supply and the demand in the information market is a simple economic one: the quantitative and qualitative resources of training institutions are not sufficient to enable them to anticipate new demands of the market or to keep abreast of rapidly evolving technology. 


\section{The 1990 state-of-the-art study - Functional analysis of the curricula in the information services sector}

This study was executed under the authority of NBBI (Netherlands Organization for Libraries and Information Services) by the University of Leiden. NBBI as the national R\&D organization in the field of information management, deemed it necessary to carry out a thorough research into the state-of-theart in the balance between supply and demand of trained information professionals.

The research concentrated on three areas:

- the extent and content of the demand of the employment market;

- the supply of education and training and its levels and varieties;

- the extent to which the mutual adaptation of supply and demand was adequate or not.

The methodology for the research was mainly based on questionnaires - 968 questionnaires were sent out to information services sector professionals as well as to graduate students of the various education and training institutions both in the public (polytechnics, universities) and private sector in the Netherlands and 422 questionnaires were returned. In addition, telephone interviews were held with key professionals in Germany, Belgium (Flanders), England, Scotland, France and in the US. Finally, desk research into the (inter)national situation was carried out in order to clarify the terminology and to corroborate the hypotheses used.

The results give some explanation for the lack of adaptation between supply and demand in indicating that although the polytechnic and university curricula had been modified to cater for new developments as information technology and economics of information, the employment market was not aware of these changes.

The study recommended some actions for improvement: educators were urged to put more effort into the awareness and marketing of curricula. A direct dialogue between the educators and the employers is necessary for a better understanding of each other's needs. Within standard curricula more opportunities for 'work placement' should be created. The development of professional standards could lead to a commonly accepted professional status as well as to vocational qualification. An inventory of curricula is to be updated on a regular basis. Its results are to be communicated to the employers.

On their side, working professionals need to update their knowledge of management and communication techniques as well as of automation. Postgraduate training in the public sector as well as commercial training packages try to satisfy these demands. However, the sheer number of these training facilities as well as the variety with respect to duration, content and qualifications, reinforce the fragmented image of the training sector: there is a need for coordination of these initiatives.

\section{Reactions to this state-of-the-art study}

As a reaction to the results and recommendations of the state-of-the-art study, new initiatives were taken by schools and training institutions. National organizations like NBBI, the Netherlands Council for Libraries and Information Services, the Netherlands Centre for Public Libraries and Literature, the various professional associations and learned societies immediately acted by initiating new studies and seminars and meetings focused on how to improve communication between educators and employers. Means were sought to improve the innovatory aspects of training courses and to regularly market the training curricula to practitioners.

The state-of-the-art study led to, among other things, a broad discussion in 1991 between representatives of both the education and training sector and the employment market. This workshop - Education and Practice - considered a number of important questions such as:

- $\quad$ The relationship between education and training and practice

The study had identified a communication gap between the two parties as well as a lack of awareness on the employers' side of the content and opportunities the curricula can offer to trainees. 
As a solution the workshop suggested a more structured dialogue between the two parties, as in fact such a dialogue already exists in the Netherlands, if only on an informal basis.

- $\quad$ The supply and demand in the education and training sector

The gap between education and training institutions and practice tends to grow; practitioners have no formal ways of influencing curricula. The supply is not sufficiently diversified: education and training institutions should try to identify the various levels of practical work within the employment market and adapt their curricula to these levels.

- The development of vocational qualifications

Both in the Netherlands and abroad the lack of commonly accepted or even standardized vocational qualifications gives rise to the fragmentation of the information services sector and consequently of education and training. The traditional information professional - the library worker - is still not highly respected by society, whereas the "new age" information professional - the information technology expert - has a better image and is better rewarded. The Dutch professional associations decided to harmonize efforts in establishing vocational qualifications.

- An international state-of-the-art

Information work is not or should not be limited to individual countries. It is preeminently a crossborder activity. Insight in similar activities in other countries of the EC and beyond could add value to national activities such as those undertaken by the Dutch information services sector.

In the discussions between educators and employers if was therefore decided to execute a survey on the relationship between the education and training sector for information professionals and the employment market in a number of ECC member states. This survey is reviewed briefly in the next section.

\section{The 1992 survey New Markets for the Information Professional?}

This survey, initiated by NBBI within its International Monitor Function, concentrated on two large European countries with an extensive tradition in library work as well as in the application of information technology (France and Great Britain). The results of the survey are briefly summarized as follows.

The aim was to explore the way educators and professional bodies in the information services sector respond to developments in the employment sector, more specifically in the emerging market.

As already stated, it is assumed that there is a tension between the traditional employment market and a new broader market: employment in the traditional market is decreasing whereas it is rising in the new market. Career development of information professionals is highly dependent on whether educators respond adequately to the changes in the employment market. Both in France and in Great Britain a number of trends have been identified which are analogous to the Dutch situation.

In France there is a strong information and technology awareness. Cultural policy furthers the access of knowledge for all groups of the population. It follows that continuing education for the better use of information and knowledge constitutes its main objective. Government determines the training policy and controls the careers of the state personnel. Finally, there is a statutory requirement for employers to provide their personnel with continuing professional development. In comparison to other countries growth in the traditional market is not decreasing. This is caused by the fact that the promotion of library development has become an important objective of recent government policy. The creation of the Bibliothèque de France will bring about many opportunities in traditional and new jobs.

In Great Britain the traditional market is deeply influenced by the lack of government policy in the field of libraries and information technology. The international economic position of the British information industry remains important. Government control of the education system for the information services sector is continuously diminishing. The professional associations' accreditation system of the curricula 
of the library and information schools has influenced standards of professional education. The initiative of the British government to develop and standardize National Vocational Qualifications is to be highly commended appreciated and would be an example for other countries to follow.

\section{An assessment of curricula}

From the early Nineties onwards education and training institutions in both the public and private sectors put considerable effort into updating their curricula. Among the Dutch Polytechnics and Colleges providing the six schools of librarianship self-evaluations were initiated. A number of trends in the education sector were observed.

- the decrease in the number of incoming full-time students;

- the negative image of the profession (it is assumed that this negative image refers specifically to the library profession);

- the need for up-to-date and market-oriented curricula;

- $\quad$ the need for job training during initial education;

- $\quad$ an awareness of the new market.

On behalf of the Board of the Association of Dutch Polytechnics and Colleges (an advisory body to the Minister of Education and Science) two major initiatives were taken between 1991 and 1993.

The 'education map' consists of 25 'higher economic disciplines', 100 different main subjects (of which library and information science is one), 37 Polytechnics (six of them offering library and information curricula) and 60,000 students. Because of this variety of disciplines and specialities it had become difficult to distinguish one main subject from another. An assessment committee installed in 1991 therefore suggested eight large disciplines instead of 25 , and as a consequence, library and information curricula became part of the larger subject of 'information management'.

The Board of the Association of Dutch Polytechnics and Colleges published a report Library and information science and publishing and book marketing, which recommended the following options
for innovation:

- a thorough renewal of the current study programme in library and information science on the basis of a new future-oriented image of the profession as well as on clear-cut choices in terms of the jobs for which students are trained;

- $\quad$ a reduction in the number of Polytechnic study programmes for library and information science in view of decreasing student numbers and the additional investment need to update curricula. (It appeared that the critical minimum for the intake per Polytechnic (six in all) should be 80 to 100 first-year students. In 1992362 first-year students applied for entry in the six schools, and if this situation continued only three of the schools could survive);

- $\quad$ a regular dialogue with potential employers so as to be able to determine more precisely what job profiles the market requires now and in the future.

\section{Reactions to the assessments by the professional associations and practitioners}

The Polytechnics themselves will all six in their own way mobilize efforts to develop their curricula, to establish a better understanding between educators and employers and to enhance the effectiveness
of the education system.

The professional associations and practitioners reacted by making the following suggestions: - information professionals with a Polytechnic degree should be able not only to process
documents but also to manage their contents; 
- $\quad$ one general professional image will not come about as practice is very diverse - instead a varied image should be promoted;

- teachers at the Polytechnics should be able to update their knowledge and to participate more actively in practice;

within the Dutch public library sector the image of the information professional as an 'information expert' with little knowledge of the institutional framework of public libraries will not thrive in public library work. Public libraries would therefore not hire graduates from the Polytechnics.

\section{A look to the future}

Looking back at recent discussions on the information professional in the Dutch information services sector a final comment remains to be made; information processing and handling is not institutionbound but is an independent activity.

Libraries, technology and communication are instrumental to the transfer of knowledge between source and user. As long as educational curricula remain too closely related to these instruments or institutions as physical entities, innovation will be hard to achieve and the position of the traditional information professional will not improve. It would be preferable to relate functions of the information professional to processes. This is not a plea for neglecting physical collections of books and other materials. It rather calls for the enrichment of the information professional's job: the information professional should not so much deliver information but knowledge to his user - he should fully exploit the knowledge which is stored in collections and create new information products.

\section{Sources}

Van Trier, G. M. Informatieverzorging 2000 (Information 2000): a Dutch view. The Hague: RABIN, 1992 (Rapport/RABIN, ISSN 0924-5944; 8).

Some thoughts on the relationship between educators and the employment market. Contribution to a discussion meeting of the Netherlands Association of Libraries. The Hague, 1993 (unpublished paper).

Ruiters, F. A. Functiegerichte analyse van opleidingen in de informatieverzorging (A job related analysis of education and training curricula for information professionals). The Hague: NBBI, 1990.

Laqueur, M. A. M. New markets for information professionals? The Hague: NBBI, 1992.

Higher economic education as an economic trade. Report of the Advisory Committee Higher Economic Education. The Hague: HBO-Raad, Novèmber 1991.

Quality for the user of information. Report of the Assessment Committee Library and Information Schools. The Hague: HBO-Raad, May 1993.

Newsletter of the Dutch Association of Librarians. Documentalists and Literature Researchers (NVB). Utrecht: NVB, August 1993.

Hope and perspective? OPEN 25, 1993, pp7/8. 